\title{
Benefits of Fish Oil Consumption over Other Sources of Lipids on Metabolic Parameters in Obese Rats
}

\author{
Paula Novato Gondim ${ }^{1}$, Priscila Vieira Rosa ${ }^{2}$, Daniel Okamura ${ }^{2}$, Viviam De Oliveira Silva ${ }^{1}$, \\ Eric Francelino Andrade ${ }^{1}$ (DD), Daniel Arrais Biihrer ${ }^{1}$ and Luciano José Pereira ${ }^{3, *}$ \\ 1 Department of Veterinary Medicine, Federal University of Lavras (UFLA), Minas Gerais 37200-000, Brazil; \\ pngondim@hotmail.com (P.N.G.); vivian_osbio@yahoo.com.br (V.D.O.S.); \\ ericfrancelinoandrade@gmail.com (E.F.A.); arrais.daniel@gmail.com (D.A.B.) \\ 2 Department of Animal Sciences, Federal University of Lavras (UFLA), Minas Gerais 37200-000, Brazil; \\ priscila@dzo.ufla.br (P.V.R.); danielokamura@hotmail.com (D.O.) \\ 3 Department of Health Sciences, Federal University of Lavras (UFLA), Minas Gerais 37200-000, Brazil \\ * Correspondence: lucianopereiraufla@gmail.com; Tel.: +55-353-829-5211
}

Received: 6 November 2017; Accepted: 22 December 2017; Published: 10 January 2018

\begin{abstract}
This study evaluated the effect of the consumption of different levels and sources of lipids on metabolic parameters of Wistar rats. Animals were fed with high-fat diet (HFD) containing 20\% of lard for 12 weeks to cause metabolic obesity. Subsequently, the animals were divided into six groups and were fed diets with lipid concentrations of $5 \%$ or $20 \%$ of lard (LD), soybean oil (SO) or fish oil (FO), for 4 weeks. Data were submitted to analysis of variance (two-way) followed by Tukey post hoc test $(p<0.05)$. The groups that consumed FO showed less weight gain and lower serum levels of triacylglycerol (TAG), total cholesterol and fractions, aspartate aminotransferase (AST) activity, atherogenic index, less amount of fat in the carcass, decreased Lee index and lower total leukocyte counting $(p<0.05)$. These same parameters were higher in LD treatment $(p<0.05)$. In the concentration of $20 \%$, carcass fat content, blood glucose levels, as well as alanine aminotransferase (ALT) and gamma glutamyl transferase (GGT) decreased in FO groups $(p<0.05)$. The $\mathrm{SO}$ group had intermediate results regarding the other two treatments (FO and LD). We concluded that fish oil intake was able to modulate positively the metabolic changes resulting from HFD.
\end{abstract}

Keywords: polyunsaturated fatty acids (PUFA); plasma lipids; dietary fat; $n-3$ fatty acids; metabolic syndrome; $n-6$ fatty acids; saturated fatty acids

\section{Introduction}

Obesity is a chronic disease [1] with a multifactorial etiology characterized by excessive accumulation of fat in the body [2]. The prevalence of obesity has reached epidemic proportions in many countries. It is considered pandemic and a serious public health problem [3]. In 2014, more than 1.9 billion adults were overweight worldwide and out of these, more than 600 million people were obese [2]. In developing countries, it is estimated that about $52.5 \%$ of the population is overweight and $17.9 \%$ are obese [4]. Projections for 2022 are that the prevalence of obesity may reach $24.8 \%$ [5].

The main cause of excessive accumulation of fat comes from an imbalance between the number of calories consumed and expended [6]. This dysfunction is an important risk factor for the development of comorbidities with high morbidity and mortality, such as cardiovascular disease (CVD), insulin resistance, dyslipidemia, fatty liver, diabetes mellitus, metabolic syndrome [2] and colon, prostate and breast cancer; musculoskeletal (osteoarthritis, risk of fractures, joints injuries) and inflammatory disorders [7], which reduce the quality of life and increase health care costs.

There is evidence that obesity has a positive relationship with lipid composition of the diet. Western diets reflect this, since large amounts of saturated fatty acid (SFA) are consumed along with a 
high $n-6: n-3$ ratio [7,8]. Fatty foods rich in long-chain SFA may contribute to the accumulation of lipids in the body and to dyslipidemias $[9,10]$. On the other hand, the consumption of unsaturated fatty acids can reduce these changes [11,12]. Among them, the polyunsaturated fatty acids (PUFA) n-3 and n-6 represented by essential fatty acids (EFA) and its co-products are highlighted. Vegetable oils such as soybean oil are rich sources of n-6 PUFA (arachidonic acid-ARA and linoleic acid-LNA) [13], whereas cold-water fishes have great proportions of $n-3$ PUFA ( $\alpha$-linolenic acid-ALA, EPA and DHA) [14].

These EFA cannot be produced in the animal body due to the absence of specific elongases and desaturases enzymes [15]. Therefore, they need to be obtained from their diet. Besides being part of the plasma membranes, EFA play a key role in the homeostasis. LNA is the ARA precursor, essential for the formation of pro-inflammatory eicosanoids. On the other hand, ALA creates the eicosapentaenoic acid (EPA) and docosahexaenoic acid (DHA), which are required in retinal cells, in the brain and which generates mediators with low inflammatory potential [16].

Previous studies have demonstrated the effects of lipogenic $n-6$ and lipolytic $n-3$ [13,17]. The latter reduces insulin resistance [18], inflammatory diseases such as arthritis [7], reduces the risk of CVD, such as atherosclerosis and dyslipidemia involving TAG, total cholesterol and very-long-density lipoprotein (VLDL) $[11,19,20]$.

A better understanding of the metabolic effects of dietary fatty acids (FA) on a daily basis is essential, especially when obesity is already established and people tend to avoid the consumption of oils and fat derivatives. Related experiments usually add lipid sources in the standard diet, however, in the present study, there was a total replacement of dietary lipids to obtain isolated results inherent to the source of lipids without any interference.

We assessed the effect of different quality and quantity of lipid content-lard, soybean and fish oils, in $5 \%$ and $20 \%$ concentrations-on metabolic parameters of obese rats.

\section{Materials and Methods}

\subsection{Animals}

This study was approved by the Ethics Committee on Animal Use of the Federal University of Lavras (UFLA) under protocol 042/15. All procedures complied with the guidelines of the National Council for Control of Animal Experimentation (CONCEA-SBCAL).

The Central Animal Laboratory of the Federal University of Lavras (UFLA) provided 36 male Wistar rats (Rattus norvegicus albinus) at six weeks of age. The animals were healthy, with initial mean weight of $134.8 \mathrm{~g}$ (SD $14.4 \mathrm{~g}$ ). Animals were distributed and kept in polypropylene boxes under ideal conditions recommended for the species (temperature: $22 \pm 2{ }^{\circ} \mathrm{C}$, humidity: $45 \pm 15 \%$ and light/dark cycle: $12 / 12 \mathrm{~h}$ ) throughout the experimental period.

Water and food were provided ad libitum throughout the experimental period. Food and water consumption was assessed daily and body weight measured weekly.

\subsection{Induction of Obesity}

Initially, the animals were randomly divided into groups of six animals per cage and acclimatized to the experimental conditions for one week. Then, animals were fed a hypercaloric HFD, which leads to obesity using a diet containing $20 \%$ lard for 12 weeks, as previously described by Araujo et al. [21] (Table 1). Diets were formulated and adapted from the AIN-93 [22]. 
Table 1. Diet ingredients (\%) and composition (\%) used to induce obesity for 12 weeks and NFD and HFD diets given for four weeks.

\begin{tabular}{|c|c|c|c|c|c|c|c|}
\hline & \multirow{2}{*}{ Obesity Induced } & \multicolumn{3}{|c|}{ NFD } & \multicolumn{3}{|c|}{ HFD } \\
\hline & & LD 5\% & SO $5 \%$ & FO $5 \%$ & LD 20\% & SO $20 \%$ & FO $20 \%$ \\
\hline \multicolumn{8}{|l|}{ Ingredient } \\
\hline Cornstarch and sucrose & 40.00 & 55.00 & 55.00 & 55.00 & 40.00 & 40.00 & 40.00 \\
\hline Soybean meal (48\% protein) & 8.60 & 8.60 & 8.60 & 8.60 & 8.60 & 8.60 & 8.60 \\
\hline Casein & 20.00 & 20.00 & 20.00 & 20.00 & 20.00 & 20.00 & 20.00 \\
\hline Cellulose & 5.00 & 7.00 & 7.00 & 7.00 & 7.00 & 7.00 & 7.00 \\
\hline Lard * & 20.00 & 5.00 & 0.00 & 0.00 & 20.00 & 0.00 & 0.00 \\
\hline Soybean oil † & 2.00 & 0.00 & 5.00 & 0.00 & 0.00 & 20.00 & 0.00 \\
\hline Fish oil & 0.00 & 0.00 & 0.00 & 5.00 & 0.00 & 0.00 & 20.00 \\
\hline Mineral mix & 3.00 & 3.00 & 3.00 & 3.00 & 3.00 & 3.00 & 3.00 \\
\hline Vitamin mix & 1.00 & 1.00 & 1.00 & 1.00 & 1.00 & 1.00 & 1.00 \\
\hline Choline bitartrate & 0.20 & 0.20 & 0.20 & 0.20 & 0.20 & 0.20 & 0.20 \\
\hline Methionine & 0.20 & 0.20 & 0.20 & 0.20 & 0.20 & 0.20 & 0.20 \\
\hline BHT & 0.02 & 0.02 & 0.02 & 0.02 & 0.02 & 0.02 & 0.02 \\
\hline Vitamin E & 0.02 & 0.02 & 0.02 & 0.02 & 0.02 & 0.02 & 0.02 \\
\hline \multicolumn{8}{|l|}{ Composition } \\
\hline Protein & 20.91 & 20.98 & 21.00 & 20.87 & 20.83 & 20.95 & 21.01 \\
\hline Energy (kJ/g) & 18.41 & 15.00 & 15.06 & 14.99 & 18.45 & 18.20 & 18.39 \\
\hline Fat & 22.10 & 4.99 & 5.01 & 5.08 & 20.09 & 20.15 & 20.01 \\
\hline Fiber & 5.40 & 7.38 & 7.23 & 7.48 & 7.37 & 7.29 & 7.31 \\
\hline Phosphor & 0.20 & 0.20 & 0.20 & 0.20 & 0.20 & 0.20 & 0.20 \\
\hline Calcium & 0.20 & 0.20 & 0.20 & 0.20 & 0.20 & 0.20 & 0.20 \\
\hline
\end{tabular}

NFD, normal-fat diet; HFD, high-fat diet; LD, lard; SO, soybean oil; FO, fish oil; BHT, butylhydroxytoluene. * Refined lard (Sadia $\left.{ }^{\circledR}\right) ;$ † Cargill ${ }^{\circledR}$, São Paulo, SP, Brazil.

The chemical composition of the diets was analyzed according to the standard methods established by AOAC (2000) [23].

The addition of $2 \%$ soybean oil on diet composition was required to avoid deficiency of EFA in the animals. All the ingredients were mixed, pelleted and frozen. The diet was given daily at room temperature. At the end of the induction period, the Lee index was obtained to confirm obesity (defined by values above 0.300 ) [24,25].

\subsection{Experimental Period}

After obesity was confirmed, the rats were randomly redistributed into six groups of six animals each. The experimental design was completely randomized in a factorial arrangement $(3 \times 2)$, consisting of three different lipids added to the diet (lard, soybean oil and fish oil) in two different concentrations: 5\% normal-fat diet (NFD) and 20\% HFD, comprising six treatments with six replicates each (Table 1). The diets were given for 4 weeks. The fish oil was extracted from salmon and it was acquired from a commercial industry. The diets were prepared weekly to minimize oxidation of the lipid sources. The schematic representation of the experimental design over time is shown in Figure 1. 


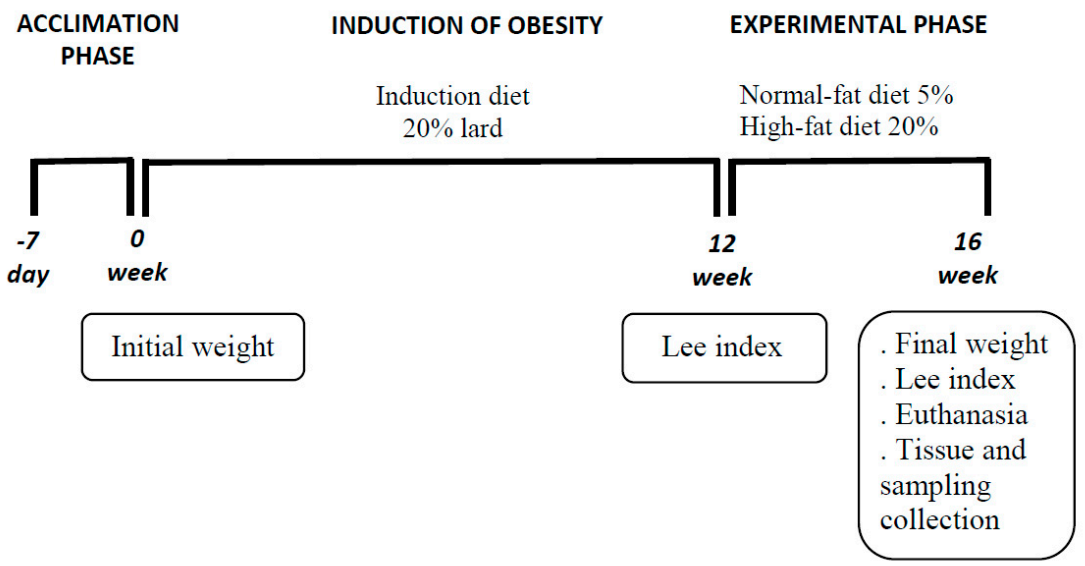

Figure 1. Schematic representation of the experimental design over time.

\subsection{Fatty Acids Profile}

Fatty acids profile of the experimental period diets was estimated based in a previous analysis of experimental diets (Table 2). Briefly, the previous analysis evaluated total lipid content using a modification of the method proposed by Folch, Less and Staney [26]. FA profile was determined using a GC2010 gas chromatograph (GC) (Shimadzu, Kyoto, Japan) equipped with a flame ionization detector and a SP-2560 fused silica capillary column $(100.0 \mathrm{~m} \times 0.25 \mathrm{~mm}, 0.20 \mu \mathrm{m}$ film; Supleco, Sigma-Aldrich, St. Louis, MO, USA). FA peaks were integrated using a GC solution chromatography software (version 4.02) and peaks were identified by comparison to known standards (37 Component FAME Mix; Supelco, Sigma-Aldrich, Darmstadt, Germany).

Table 2. Estimated fatty acids profile (\%) of the experimental diets given for four weeks.

\begin{tabular}{|c|c|c|c|c|c|c|}
\hline \multirow{2}{*}{ Fatty-Acid (\%) } & \multicolumn{3}{|c|}{ NFD } & \multicolumn{3}{|c|}{ HFD } \\
\hline & LD 5\% & SO $5 \%$ & FO $5 \%$ & LD 20\% & SO $20 \%$ & FO $20 \%$ \\
\hline C14:0 & 0.065 & 0.023 & 0.36 & 0.50 & 0.03 & 0.90 \\
\hline $\mathrm{C} 14: 1(n-5)$ & 0.00 & 0.01 & 0.01 & 0.00 & 0.04 & 0.05 \\
\hline $\mathrm{C} 16: 0$ & 15.00 & 1.94 & 2.42 & 60.00 & 7.74 & 9.67 \\
\hline C16:1 (n-7) & 1.00 & 0.00 & 0.00 & 4.00 & 0.02 & 0.00 \\
\hline C17:0 & 0.25 & 0.02 & 0.03 & 1.00 & 0.09 & 0.11 \\
\hline C17:1 (n-7) & 0.15 & 0.02 & 0.11 & 0.60 & 0.07 & 0.44 \\
\hline C18:0 & 6.55 & 2.62 & 2.27 & 26.20 & 10.48 & 9.07 \\
\hline C18:1 (n-9) & 18.55 & 1.34 & 0.68 & 74.20 & 5.34 & 2.71 \\
\hline C18:2 (n-6) & 6.85 & 4.76 & 1.26 & 27.40 & 19.05 & 5.04 \\
\hline C18:3 (n-3) & 0.00 & 0.75 & 0.41 & 0.00 & 3.02 & 1.66 \\
\hline C20:0 & 0.10 & 0.07 & 0.00 & 0.38 & 0.29 & 0.00 \\
\hline C20:1 (n-9) & 0.30 & 0.06 & 0.35 & 1.34 & 0.29 & 1.38 \\
\hline C20:2 (n-6) & 0.25 & 0.03 & 0.09 & 0.90 & 0.13 & 0.38 \\
\hline C20:3 (n-6) & 0.00 & 0.01 & 0.04 & 0.00 & 0.05 & 0.14 \\
\hline C20:4 (n-6) & 0.00 & 0.03 & 0.10 & 0.00 & 0.14 & 0.38 \\
\hline C20:5 (n-3) & 0.00 & 0.03 & 0.83 & 0.00 & 0.14 & 3.35 \\
\hline$C 22: 6(n-3)$ & 0.00 & 0.02 & 1.27 & 0.00 & 0.09 & 4.90 \\
\hline \multicolumn{7}{|c|}{ Total } \\
\hline$\Sigma$ SFA & 22.40 & 4.88 & 5.38 & 88.60 & 19.01 & 20.98 \\
\hline$\Sigma$ MUFA & 20.00 & 1.43 & 1.15 & 79.30 & 5.26 & 4.21 \\
\hline$\Sigma$ PUFA & 7.10 & 5.68 & 3.95 & 28.10 & 22.21 & 15.32 \\
\hline$\sum n-3$ & 0.00 & 0.81 & 2.48 & 0.00 & 3.74 & 9.45 \\
\hline$\sum n-6$ & 7.10 & 4.87 & 1.48 & 28.19 & 19.01 & 5.58 \\
\hline$\sum n-9$ & 18.85 & 1.39 & 1.03 & 74.4 & 5.26 & 4.33 \\
\hline$n-3 / n-6$ & 0.00 & 0.17 & 1.68 & 0.00 & 0.17 & 1.68 \\
\hline
\end{tabular}

NFD, normal-fat diet; HFD, high-fat diet; LD, lard; SO, soybean oil; FO, fish oil. 


\subsection{Euthanasia and Sampling}

At the end of the experimental period, each rat was weighed to calculate the Lee index. Weight gain (difference between the initial and final weight) was determined.

After eight hours of fasting, the animals were sacrificed by cardiac puncture under anesthesia (sodium thiopental $50 \mathrm{mg} / \mathrm{kg}$, ip). Blood samples were collected for biochemical analysis. Whole blood was used for white blood cell count analysis by an automated hematology analyzer SDH-20 (Labtest Diagnostica S/ ${ }^{\circledR}$, Lagoa Santa, MG, Brazil). The serum was used for analysis of the following biochemical parameters: glycemia, total cholesterol, high-density lipoprotein (HDL) cholesterol, TAG, ALT, AST, gamma-glutamyltransferase (GGT) and C-reactive protein (CRP), using commercial specific colorimetric kits (Labtest Diagnostica S/ ${ }^{\circledR}$, Lagoa Santa, MG, Brazil) and specific C-peptide for rats by ELISA (Merck Millipore, Darmstadt, Germany). The levels of low-density lipoprotein (LDL) cholesterol + VLDL-cholesterol fractions from each animal were obtained using the following equation: LDL-C + VLDL-C = total cholesterol-HDL-C [27]. The atherogenic index was calculated according to the relation (VLDL-C + LDL-C)/HDL-C [28].

After blood collection, the animals' chest and abdominal cavities were opened to expose the internal organs. Heart, liver and right kidney were collected and weighted. Relative organ mass was calculated in relation to the weight of the clean carcass (organ weight/clean carcass weight) [29].

\subsection{Histological Analysis}

For histological analysis, epididymal fat was collected, fixed in 10\% buffered formaldehyde and processed routinely for preparation of histological slides with paraffin sections $3 \mu \mathrm{m}$ thick, stained with hematoxylin and eosin and mounted in resinous Entellan ${ }^{\circledR}$ media (Merck Millipore, Darmstadt, Germany). Histomorphometric analyses were performed using optical microscopy employing a capture system and image analysis, which consists of a binocular Olympus CX31 microscope (Olympus Optical do Brazil Ltda, São Paulo, SP, Brazil) with an attached camera (SC30 CMOS Color Camera for Light Microscopy Olympus Optical do Brazil Ltda, São Paulo, SP, Brazil). Measurements were conducted using Image-Pro ${ }^{\circledR}$ Express software (Targetware Informática Ltda of Brazil, Água Branca, SP, Brazil).

\subsection{Morphometric Analysis of Adipose Tissue}

Epididymal fat cells diameter was determined by measuring the largest distance between two membrane limits in opposite sides [30]. Adipocyte area was determined by measuring the delimitation of the cells and tissue density was calculated using a known squared area superimposed on certain fields of the captured images. Then, the analysis of adipocytes density (number of adipocytes per unit area of tissue) was performed as previously described [31].

All histologic measurements were performed through blind assessment by a single trained evaluator.

\subsection{Body Composition}

Carcasses of animals were weighed, processed and submitted to the analysis of fat and protein using the FoodScanTM NIR (near infra-red) meat analyzer (Foss, Warrington, UK) as performed by Vickers [32]. For carcass analysis, skin, legs, head and viscera were removed.

\subsection{Data Analysis and Statistics}

Data were submitted to two-way analysis of variance (ANOVA) followed by a Tukey post-hoc test using the Sisvar 5.5 Build 82 software (UFLA, Minas Gerais, Brazil) [33] and the results are expressed as means with their standard deviations (SD). A significance level of $p<0.05$ was used. 


\section{Results}

After 12 weeks, all animals fed the 20\% lard diet were considered obese (Lee index $>0.300$ ). Subsequently, by the end of the fourth-week of the experimental period, the daily food intake was lower in the HFD groups in relation to NFD. Weight gain of animals was higher in the group that consumed LD than in other groups (Table $3 ; p<0.05$ ).

Table 3. The daily feed intake (g) and body weight gain $(\mathrm{g})$ of obese rats fed diets containing $5 \%$ or $20 \%$ lard (LD), soybean oil (SO) or fish oil (FO) in 4 weeks.

\begin{tabular}{|c|c|c|c|}
\hline$\%$ & LD & SO & FO \\
\hline & \multicolumn{3}{|c|}{ Consumption $(\mathrm{g} / \pm \mathrm{SD})$} \\
\hline 5 & $25(3)$ & $28(3) *$ & $27(2)$ \\
\hline \multirow[t]{2}{*}{20} & $20(2)$ & $18(1)$ & $18(3)$ \\
\hline & \multicolumn{3}{|c|}{ Body weight gain $(\mathrm{g} / \pm \mathrm{SD})$} \\
\hline 5 & $324(5)^{b}$ & $303(24)^{a}$ & $277(17)^{a}$ \\
\hline 20 & $344(35)^{b}$ & $285(28)^{a}$ & $272(26)^{a}$ \\
\hline
\end{tabular}

Values were means $(n=6)$, with their standard deviations (SD). ${ }^{*}$ Differ between the different lipid concentrations by Tukey test $(p<0.05)$. a,b Followed by different letters differ among diets with the same lipid concentration by Tukey test $(p<0.05)$.

Among the NFD groups, results were similar for glycemia. In the HFD groups, animals fed lard showed blood glucose levels $8 \%$ higher than SO and $18 \%$ higher than FO groups (Table $4 ; p<0.05$ ). In turn, FO had a reduction of $11 \%$ in blood glucose compared to SO. Regarding TAG, a diet rich in FO was effective in reducing this variable, regardless of the concentration (Table $4 ; p<0.05)$. Among HFD groups, the LD group had the highest levels of TAG, which were $25 \%$ higher than SO and $56 \%$ higher than FO (Table 4; $p<0.05$ ). Moreover, the SO group was $26 \%$ higher than FO. Increased lard content in the LD group diet exacerbated the values of this parameter, from $63 \mathrm{mg} / \mathrm{dL}$ to $72 \mathrm{mg} / \mathrm{dL}$ (Table 4; $p<0.05)$. Instead, when the FO group content was increased, we observed a more marked reduction of TAG, from $51 \mathrm{mg} / \mathrm{dL}$ to $40 \mathrm{mg} / \mathrm{dL}$ (Table $4 ; p<0.05$ ). Regarding C-peptide, the LD 5\% group had higher levels compared to FO 5\% and among HFD groups, LD was 36.9\% higher than SO and $43.7 \%$ higher than FO (Table $4 ; p<0.05)$.

Table 4. Parameters related to serum levels of glucose (mg/dL), triacylglycerol $(\mathrm{mg} / \mathrm{dL})$ and peptide C of obese rats fed diets containing $5 \%$ or $20 \%$ lard (LD), soybean oil (SO) or fish oil (FO) in 4 weeks.

\begin{tabular}{cccc}
\hline$\%$ & LD & SO & FO \\
\hline \multicolumn{3}{c}{ Glucose $(\mathrm{mg} / \mathrm{dL} \pm \mathrm{SD})$} \\
\hline 5 & $170(5)$ & $162(8)$ & $162(7)^{\mathrm{B}}$ \\
20 & $174(8)^{\mathrm{c}}$ & $160(10)^{\mathrm{b}}$ & $143(7)^{\mathrm{A}, \mathrm{a}}$ \\
\hline \multicolumn{4}{c}{ Triacylclycerol (mg/dL $\pm \mathrm{SD})$} \\
\hline 5 & $63(2)^{\mathrm{A}, \mathrm{b}}$ & $55(10)^{\mathrm{a}, \mathrm{b}}$ & $51(9)^{\mathrm{B}, \mathrm{a}}$ \\
20 & $72(7)^{\mathrm{B}, \mathrm{c}}$ & $54(8)^{\mathrm{b}}$ & $40(6)^{\mathrm{A}, \mathrm{a}}$ \\
\hline \multicolumn{4}{c}{ Peptide C (pM $\pm \mathrm{SD})^{\mathrm{c}}$} \\
\hline 5 & $496(94)^{\mathrm{b}}$ & $335(85)^{\mathrm{ab}}$ & $223(89)^{\mathrm{a}}$ \\
20 & $490(165)^{\mathrm{b}}$ & $309(112)^{\mathrm{a}}$ & $276(100)^{\mathrm{a}}$ \\
\hline
\end{tabular}

Values were means $(n=6)$, with their standard deviations (SD). ${ }^{\mathrm{a}, \mathrm{b}, \mathrm{c}}$ Followed by different letters differ among diets of the same lipid concentration by Tukey test $(p<0.05)$. ${ }^{A, B}$ Followed by different letters differ in same diet with different lipid concentrations by Tukey test $(p<0.05)$.

Regarding serum lipid levels, total cholesterol was lower in the groups receiving FO (Table $5 ; p<0.05$ ). By increasing the concentration of this lipid to $20 \%$, there was a reduction of about 38\% (Table $5 ; p<0.05$ ). Still regarding this parameter, the LD and SO groups remained equal. In relation to HDL-C among NFD, SO showed higher values than FO (Table 5; $p<0.05$ ). However, among HFD, FO had lower levels even when compared with FO 5\% (Table 5; $p<0.05$ ). The LDL-C + VLDL-C fraction, as well as the atherogenic index 
followed the same behavior of the total cholesterol (Table 5; $p<0.05$ ). At $5 \%$ concentrations, among the NFD groups, the atherogenic index for the FO groups was on average $36 \%$ lower than other groups (59\% lower than the HFD at 20\%) (Table 5; $p<0.05$ ). When lipid content in the diets increased to $20 \%$, the reduction in the atherogenic index reached $35 \%$ (Table $5 ; p<0.05$ ).

Table 5. Parameters related to serum levels of total cholesterol (mg/dL), HDL-cholesterol (mg/dL), $\mathrm{LDL}+\mathrm{VLDL}$-cholesterol $(\mathrm{mg} / \mathrm{dL})$ and atherogenic index of obese rats fed diets containing $5 \%$ or $20 \%$ lard (LD), soybean oil (SO) or fish oil (FO) in 4 weeks.

\begin{tabular}{|c|c|c|c|}
\hline$\%$ & LD & SO & FO \\
\hline & \multicolumn{3}{|c|}{ Total cholesterol (mg/dL $\pm \mathrm{SD})$} \\
\hline 5 & $72(6)^{b}$ & $73(8)^{b}$ & $56(8)^{\mathrm{B}, \mathrm{a}}$ \\
\hline \multirow[t]{2}{*}{20} & $71(5)^{b}$ & $69(5)^{\mathrm{b}}$ & $35(5)^{A, a}$ \\
\hline & \multicolumn{3}{|c|}{ HDL cholesterol (mg/dL $\pm \mathrm{SD})$} \\
\hline 5 & $37(4)^{a, b}$ & $40(2)^{b}$ & $35(4) \mathrm{B}, \mathrm{a}$ \\
\hline \multirow[t]{2}{*}{20} & $36(3)^{b}$ & $37(2)^{\mathrm{b}}$ & $25(3)^{A, a}$ \\
\hline & \multicolumn{3}{|c|}{ LDL + VLDL cholesterol (mg/dL \pm SD) } \\
\hline 5 & $35(5)^{b}$ & $33(7)^{b}$ & $21(4)^{\mathrm{B}, \mathrm{a}}$ \\
\hline \multirow[t]{2}{*}{20} & $35(3)^{b}$ & $32(5)^{b}$ & $10(4)^{A, a}$ \\
\hline & \multicolumn{3}{|c|}{ Atherogenic index $( \pm \mathrm{SD})$} \\
\hline 5 & $0.96(0.17)^{b}$ & $0.83(0.11)^{b}$ & $0.58(0.11)^{\mathrm{B}, \mathrm{a}}$ \\
\hline 20 & $0.99(0.06)^{b}$ & $0.88(0.07)^{b}$ & $0.38(0.09)^{\mathrm{A}, \mathrm{a}}$ \\
\hline
\end{tabular}

Values were means $(n=6)$, with their standard deviations (SD). ${ }^{\mathrm{a}, \mathrm{b}}$ Followed by different letters differ among diets of the same lipid concentration by Tukey test $(p<0.05)$. ${ }^{A, B}$ Followed by different letters differ in same diet with different lipid concentrations by Tukey test $(p<0.05)$.

Different lipid sources did not alter the relative weight of the kidney, liver and heart. However, a lower percentage of fat in the carcass was observed in animals fed with FO (Table $6 ; p<0.05$ ). On the other hand, the protein percentage did not change. The Lee index was also lower in animals fed FO, regardless of the concentration (Table 6; $p<0.05$ ). Among HFD, the diameter and the area of adipocytes in the epididymal fat tissue of the FO group was reduced when compared to the LD group (Table 6; $p<0.05$ and Figure 2). When diets of LD and SO changed to $20 \%$, there was an increase in the diameter and size of adipocytes (Table 6; $p<0.05$ ). There were no significant differences for adipocytes density.

Table 6. Parameters related to fat in the carcass $(\%)$, Lee index and diameter $(\mu \mathrm{m})$ and area $\left(\mu \mathrm{m}^{2}\right)$ of adipocytes from epididymal fat of obese rats fed diets containing $5 \%$ or $20 \%$ lard (LD), soybean oil (SO) or fish oil (FO) in 4 weeks.

\begin{tabular}{cccc}
\hline$\%$ & LD & SO & FO \\
\hline \multicolumn{3}{c}{ Carcass fat $(\% \pm S D)$} \\
\hline 5 & $9.6(0.3)^{\mathrm{b}}$ & $9.9(0.7)^{\mathrm{b}}$ & $8.2(1.4)^{\mathrm{a}}$ \\
20 & $10.4(0.8)^{\mathrm{b}}$ & $10.1(0.9)^{\mathrm{b}}$ & $9.0(1.1)^{\mathrm{a}}$ \\
\hline \multicolumn{3}{c}{ Lee index $( \pm \mathrm{SD})$} \\
\hline 5 & $0.309(0.009)^{\mathrm{b}}$ & $0.308(0.008)^{\mathrm{b}}$ & $0.292(0.010)^{\mathrm{a}}$ \\
20 & $0.311(0.007)^{\mathrm{b}}$ & $0.311(0.005)^{\mathrm{b}}$ & $0.296(0.010)^{\mathrm{a}}$ \\
\hline \multicolumn{3}{c}{ Diameter $(\mu \mathrm{m} / \pm \mathrm{SD})$} \\
\hline 5 & $195(13)^{\mathrm{A}}$ & $183(7)^{\mathrm{A}}$ \\
20 & $210(9)^{\mathrm{Bb}}$ & $200(9)^{\mathrm{B}, \mathrm{a}, \mathrm{b}}$ & $184(15)^{\mathrm{a}}$ \\
\hline \multicolumn{4}{c}{ Area $\left(\mu \mathrm{m}^{2} \pm \mathrm{SD}\right)$} \\
\hline 5 & $21,797(3742)^{\mathrm{A}}$ & $20,569(1906)^{\mathrm{A}}$ & $22,239(4310)$ \\
20 & $25,049(1281)^{\mathrm{B}, \mathrm{b}}$ & $23,860(2678)^{\mathrm{B}, \mathrm{a}, \mathrm{b}}$ & $21,080(1401)^{\mathrm{a}}$ \\
\hline
\end{tabular}

Values were means $(n=6)$, with their standard deviations (SD). ${ }^{\text {a,b }}$ Followed by different letters differ among diets of the same lipid concentration by Tukey test $(p<0.05)$. ${ }^{\mathrm{A}, \mathrm{B}}$ Followed by different letters differ in same diet with different lipid concentrations by Tukey test $(p<0.05)$. 


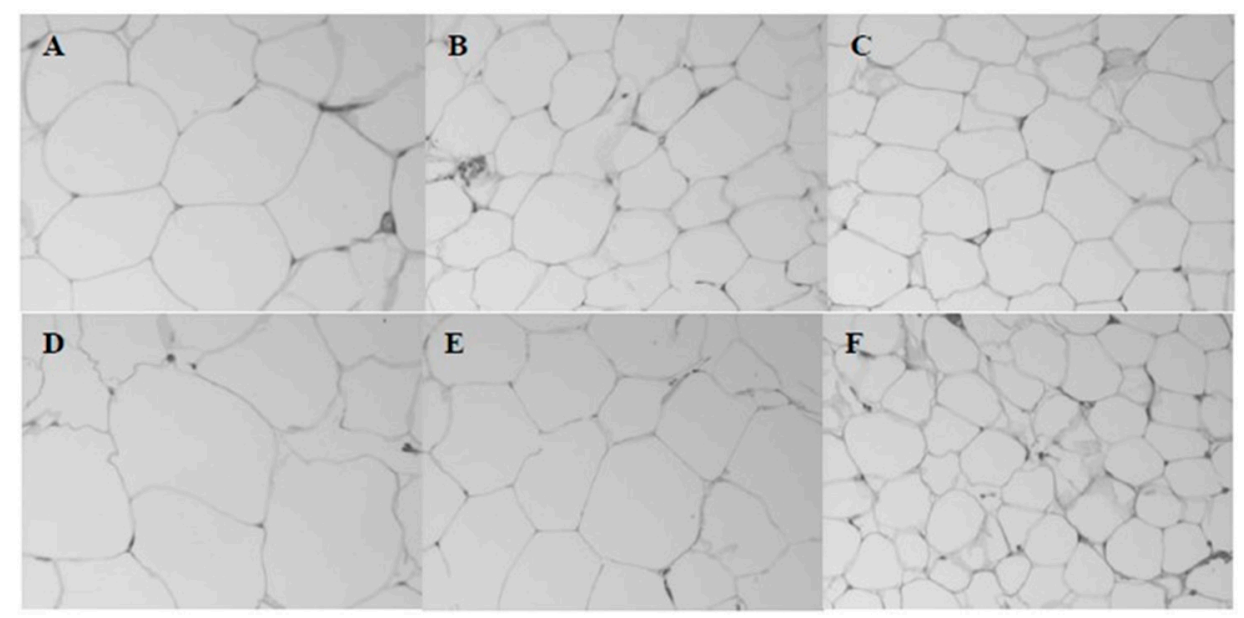

Figure 2. Adipocytes from epididymal fat of obese rats fed diets containing (A) $5 \%$ lard, (B) $5 \%$ soybean oil, (C) $5 \%$ fish oil, (D) 20\% lard, (E) 20\% soybean oil and (F) 20\% fish oil for 4 weeks.

The enzymatic activity of AST decreased $8 \%$ in the treatment with FO when compared to LD (Table 7; $p<0.05$ ). ALT and GGT increased when the lipid concentrations of LD and SO also increased in the diet (Table $7 ; p<0.05)$. FO at $20 \%$ reduced ALT enzyme activity ( $35 \mathrm{U} / \mathrm{L}$ ) compared to LD 20\% (46 U/L). Among HFD, GGT values corresponded to the following order: LD > SO > FO (Table 7; $p<0.05)$. CRP did not change between groups but total leukocyte was $21 \%$ lower in the group that consumed FO diets (Table $7 ; p<0.05$ )

Table 7. Parameters related to the enzymatic activity of aspartate aminotransferase-AST (U/L), alanine aminotransferase-ALT (U/L), gamma glutamyltransferase-GGT (U/L) and total leukocyte $\left(10^{3} / \mathrm{uL}\right)$ of obese rats fed diets containing $5 \%$ or $20 \%$ lard (LD), soybean oil (SO) or fish oil (FO) in 4 weeks.

\begin{tabular}{|c|c|c|c|}
\hline$\%$ & LD & SO & FO \\
\hline & \multicolumn{3}{|c|}{ AST (U/L/ \pm SD) } \\
\hline 5 & $135(7)^{b}$ & $132(12)^{a, b}$ & $123(4)^{\mathrm{a}}$ \\
\hline \multirow[t]{2}{*}{20} & $144(9)^{b}$ & $140(12)^{a, b}$ & $133(13)^{\mathrm{a}}$ \\
\hline & \multicolumn{3}{|c|}{$\operatorname{ALT}(\mathrm{U} / \mathrm{L} / \pm \mathrm{SD})$} \\
\hline 5 & $31(5)^{\mathrm{A}}$ & $30(3) \mathrm{A}$ & $32(3)$ \\
\hline \multirow[t]{2}{*}{20} & $46(4)^{B, b}$ & $41(5)^{B, a, b}$ & $35(5)^{a}$ \\
\hline & \multicolumn{3}{|c|}{ GGT $(\mathrm{U} / \mathrm{L} / \pm \mathrm{SD})$} \\
\hline 5 & $0.56(0.07)^{\mathrm{A}}$ & $0.55(0.04)^{\mathrm{A}}$ & $0.63(0.04)$ \\
\hline \multirow[t]{2}{*}{20} & $2.03(0.2)^{\mathrm{B}, \mathrm{c}}$ & $0.91(0.03)^{\mathrm{B}, \mathrm{b}}$ & $0.72(0.08)^{a}$ \\
\hline & \multicolumn{3}{|c|}{ Total leukocyte $\left(10^{3} / \mathrm{uL} / \pm \mathrm{SD}\right)$} \\
\hline 5 & $4.3(0.1)^{b}$ & $4.2(0.2)^{b}$ & $3.2(0.3)^{a}$ \\
\hline 20 & $4.0(0.3)^{b}$ & $4.0(0.4)^{b}$ & $3.3(0.2)^{\mathrm{a}}$ \\
\hline
\end{tabular}

Values were means $(n=6)$ with their standard deviations (SD) ${ }^{\mathrm{a}, \mathrm{b}, \mathrm{c}}$ Followed by different letters differ among diets of the same lipid concentration by Tukey test $(p<0.05)$. ${ }^{A, B}$ Followed by different letters differ in same diet with different lipid concentrations by Tukey test $(p<0.05)$.

\section{Discussion}

At the end of a 12-week period receiving a high-calorie diet $(18.41 \mathrm{~kJ} / \mathrm{g}$ ) (consisting of high fat $-20 \%$ lard), induction of obesity in the rats was confirmed and the Lee index reached values higher than $0.300[24,25]$. The main objective of this diet was to trigger not just obesity but alterations commonly associated with this pathology such as metabolic syndrome, which was demonstrated in a previous study [21]. High-fat diets are used to induce obesity for the high-calorie and lipogenesis stimulation [9]. Estadella et al. [34] observed that a 30-day fat diet containing $20 \%$ of fat was enough to 
make Wistar rats metabolically obese, with more accumulation of fat in the carcass when compared to animals receiving a standard diet. These authors concluded that the higher the intake period, the more pronounced the weight gain and adiposity.

In this study, food intake was 30\% lower in groups that received HFD because they had higher caloric levels compared to NFD. Thereby, a lower intake was sufficient to meet daily total energy requirements [35]. Similarly, Hashimoto et al. [13] observed a reduced consumption among rats receiving $H F D$, explained by the equivalence of the total energy intake regardless of the type and quantity of food ingested. However, other experiments have shown controversial results such as cafeteria diets [36,37]. Cafeteria diets use palatable food, which stimulates voluntary hyperphagia and, consequently, increase food ingestion, which differs from the present study. Herein, hyperphagia was not promoted by our diet. Therefore, satiety obtained by a high-calorie and HFD was enough to cause a smaller consumption.

Despite the lower consumption, the LD groups had higher weight gain than other diets. This result demonstrates that not only the quantity but also the quality of food intake may contribute to increased body weight [38,39]. Moreover, elevated levels of C-peptide and blood glucose indicated that a lard-rich diet was able to induce insulin resistance in animals.

Fish oil was able to attenuate obesity regardless of the concentration and it reduced weight gain, leading to Lee index values lower than 0.300 . In addition, consumption of this oil was effective in improving metabolic parameters, such as blood glucose, cholesterol and triglycerides and in reducing lipid accumulation in the carcass. These results may be attributed to fatty acids content. The $n-3$ very long-chain (VLC) PUFA acts as an intracellular marker, suppressing the expression of genes involved in lipogenesis and inducing transcription of genes involved in lipid oxidation. By binding to the PPAR and the sterol regulatory element-binding protein (SREBP) nuclear receptors, which function as transcription factors, $n-3$ can regulate the expression of genes involved in glucose and lipid metabolism [40]. This PUFA can increase oxidation of free fatty acids when it activates PPAR- $\alpha$ [41], which in turn acts on the transcription of genes encoding regulatory enzymes of this oxidation $[13,42]$. The $n-3$ VLC-PUFA also reduces cholesterol biosynthesis by inhibiting the actions of SREBP-1 and SREBP-2 [43,44]. Nakatani et al. [40] found that this modulating effect is dose-dependent, which is consistent with the present study, in which the reduction of serum glucose, TAG and total cholesterol were improved when the FO concentration was increased in the diet. Additionally, Hashimoto et al. [13] suggested that in addition to the inhibition of SREBP-1, the reduction in plasma levels of TAG observed in animals fed with a FO-rich diet was caused by the suppression of Apo-B100 synthesis by the liver and a consequent reduction in the secretion of VLDL. Moreover, we found a reduction of adipocytes' area and diameter, suggesting the possible lipolytic action induced by $n-3$ PUFA.

A risk indicator for cardiovascular disease is the atherogenic index, which was reduced in the group that consumed FO diets. This index was 35\% lower when concentrations of FO were increased to $20 \%$. In this case, the reduction of total cholesterol fractions (HDL, LDL+VLDL) reflects cholesterol lowering as a whole. The atherogenic index becomes important to evaluate the correlation between these fractions, since the higher the LDL (and the lower HDL levels), the higher the risk of atherosclerosis $[19,45]$. A 59\% reduction of this index in the FO group among HFD reflects the beneficial action of $n-3$ in reducing CVD [46].

Animals that consumed SO 5\% showed no differences in TAG levels from other NFD groups. However, with the $20 \%$ increase of this oil, a difference was evident. From obtained results, we are inclined to believe that Wistar rats have the ability to elongate and desaturate PUFA [47-49]. Soybean oil contains an ALA precursor without DHA and EPA derivatives. The increase in soybean oil concentration may increase the amount of ALA necessary for $n$ - 3 PUFA, EPA and DHA production, which may justify the reduction in TAG levels compared to the lard diet.

Regarding plasma glucose levels among HFD groups, a reduction was observed in the FO group. Studies have shown that saturated fatty acid rich-diets, besides inducing obesity, are able to increase 
blood glucose levels [34,50] due to the suppression of insulin signaling by TNF $\alpha$ and other inflammatory cytokines, as well as the excess FA, triggering insulin resistance [51-53]. Nevertheless, the $n-3$ PUFA is capable of increasing insulin sensitivity by reducing the obesity inflammatory process, as well as the increase in adiponectin levels, which is reduced when there is an excess of adipocytes [54,55].

Decreased plasma activity of ALT, AST and GGT liver enzymes in the HFD/FO group may be associated with its hepatoprotective effect. The measurement of these enzymes is associated with hepatic injury and although they are considered sensitive markers, they have different specificities and half-life time [56]. The accumulation of fat in hepatocytes occurs when the body has reached its maximum deposition capacity and oxidation and this accumulation may trigger hepatic steatosis [10,42].

Different treatments did not affect serum CRP levels, since this parameter corresponds to an acute phase protein [57]. However, the total leukocyte was reduced by an average of $21 \%$ in the FO group. This lipid is capable of modulating the inflammatory process initiated by obesity from chemical mediators [58-60]. EPA is a substrate for the production of E-series resolvins and DHA can produce D-series resolvins and protectins, which act in the blocking of neutrophil migration, infiltration and recruitment [61]. Besides, EPA is able to synthesize 3 and 5-series eicosanoids that have anti-inflammatory activity [19]. In contrast, 2 and 4-series eicosanoids with pro-inflammatory effects can be produced through ARA after the consumption of soybean oil, as in SFA-rich diets via cyclooxygenase-2 (COX-2) and toll-like receptor-4 (TLR-4) [13].

The present study showed that different compositions and concentrations of lipid diets are capable of defining the metabolic profile of rats. Lard is rich in long-chain saturated fatty acids, a fact that exacerbated features of obesity such as weight gain, increased serum levels of glucose, total cholesterol and fractions, TAG and lipid accumulation in the carcass, generating metabolic syndrome. Soybean oil, rich in LNA (n-6), kept the metabolic consequences in an intermediate state. Fish oil, rich in n-3 PUFA, especially EPA and DHA, was able to reduce these obesity-related metabolic disorders [11,62].

From the analysis, one can assume that the levels and sources of lipids contained in the diet can modulate in different ways obese animal's metabolism. Therefore, more studies are needed focusing on evaluating the mechanism of action of these FA in relation to hormones, enzymes and nuclear receptors, as well as the ideal lipid concentration, resulting only in beneficial effects.

Acknowledgments: The authors would like to thank the Coordination for the Improvement of Higher Education Personnel (Coordenação de Aperfeiçoamento de Pessoal do Nível Superior-CAPES), the Research Support Foundation of the state of Minas Gerais (Fundação de Amparo à Pesquisa do Estado de Minas Gerais-FAPEMIG), and the National Council for Scientific and Technological Development (Conselho Nacional de Desenvolvimento Científico e Tecnológico-CNPq) for their support.

Author Contributions: P.N.G., L.J.P., P.V.R. and D.O. conceived and designed the experiments; P.N.G., V.O.S. and E.F.A. performed the experiments; P.N.G., D.O. and V.O.S. contributed to statistical analysis; D.A.B. performed histopathologic analysis; P.N.G. wrote the paper; all the author contributed intellectually and revision.

Conflicts of Interest: The authors declare no conflict of interest.

\section{References}

1. Jensen, M.D.; Ryan, D.H.; Apovian, C.M.; Ard, J.D.; Comuzzie, A.G.; Donato, K.A.; Hu, F.B.; Hubbard, V.S.; Jakicic, J.M.; Kushner, R.F.; et al. Obesity Society 2013 AHA/ACC/TOS Guideline for the management of overweight and obesity in adults. J. Am. Coll. Cardiol. 2014, 63, 2985-3023. [CrossRef] [PubMed]

2. World Health Organization. Obesity and Overwheight. Fact Sheet No. 311. Available online: http:/ / www.who.int/mediacentre/factsheets/fs311/en/ (accessed on 25 June 2015).

3. Swinburn, B.A.; Sacks, G.; Hall, K.D.; McPherson, K.; Finegood, D.T.; Moodie, M.L.; Gortmaker, S.L. The global obesity pandemic: Shaped by global drivers and local environments. Lancet (Lond. Engl.) 2011, 378, 804-814. [CrossRef]

4. Brazil Ministry of Health; Department of Health Surveillance. Vigitel Brazil 2014: Risk Factors Surveillance and Protection for Chronic Diseases by Telephone Survey; Ministry of Health: Brasília, Brazil, 2014. 
5. Brazil Ministry of Health; Department of Health Surveillance; Department of Health Situation Analysis. Strategic Action Plan for Dealing with Chronic Noncommunicable Diseases (DCNT) in Brazil 2011-2022; Ministry of Health: Brasília, Brazil, 2011.

6. Marques-Lopes, I.; Marti, A.; Moreno-Aliaga, M.J.; Martínez, A. Genetics of obesity. Rev. Nutr. 2004, 17, 327-338. [CrossRef]

7. Simopoulos, A.P. The importance of the omega-6/omega-3 fatty acid ratio in cardiovascular disease and other chronic diseases. Exp. Biol. Med. (Maywood) 2008, 233, 674-688. [CrossRef] [PubMed]

8. Martin, C.; Almeida, V.; Ruiz, M.; Visentainer, J. Polyunsaturated fatty acids omega-3 and omega-6: Importance and occurrence in food. Rev. Nutr. 2006, 19, 761-770. [CrossRef]

9. Schrauwen, P.; Westerterp, K.R. The role of high-fat diets and physical activity in the regulation of body weight. Br. J. Nutr. 2000, 84, 417-427. [CrossRef] [PubMed]

10. Koonen, D.P.Y.; Jacobs, R.L.; Febbraio, M.; Young, M.E.; Soltys, C.-L.M.; Ong, H.; Vance, D.E.; Dyck, J.R.B. Increased hepatic CD36 expression contributes to dyslipidemia associated with diet-induced obesity. Diabetes 2007, 56, 2863-2871. [CrossRef] [PubMed]

11. Sato, A.; Kawano, H.; Notsu, T.; Ohta, M.; Nakakuki, M.; Mizuguchi, K.; Itoh, M.; Suganami, T.; Ogawa, Y. Antiobesity effect of eicosapentaenoic acid in high-fat/high-sucrose diet-induced obesity: Importance of hepatic lipogenesis. Diabetes 2010, 59, 2495-2504. [CrossRef] [PubMed]

12. Sampath, H.; Ntambi, J.M. Polyunsaturated fatty acid regulation of genes of lipid metabolism. Annu. Rev. Nutr. 2005, 25, 317-340. [CrossRef] [PubMed]

13. Hashimoto, Y.; Yamada, K.; Tsushima, H.; Miyazawa, D.; Mori, M.; Nishio, K.; Ohkubo, T.; Hibino, H.; Ohara, N.; Okuyama, H. Three dissimilar high fat diets differentially regulate lipid and glucose metabolism in obesity-resistant Slc:Wistar/ST rats. Lipids 2013, 48, 803-815. [CrossRef] [PubMed]

14. Tocher, D. Omega-3 long-chain polyunsaturated fatty acids and aquaculture in perspective. Aquaculture 2015, 449, 94-107. [CrossRef]

15. Turchini, G.M.; Torstensen, B.E.; Ng, W.-K. Fish oil replacement in finfish nutrition. Rev. Aquac. 2009, 1, 10-57. [CrossRef]

16. De Mattos, P.; Andrade, M.; Das, M.; Tavares Do Carmo, G. N-3 fatty acids: A link between eicosanoids, inflammation and immunity. Nm-metabólica 2006, 8, 135-143.

17. $\mathrm{Xu}$, J.; Nakamura, M.T.; Cho, H.P.; Clarke, S.D. Sterol regulatory element binding protein-1 expression is suppressed by dietary polyunsaturated fatty acids. A mechanism for the coordinate suppression of lipogenic genes by polyunsaturated fats. J. Biol. Chem. 1999, 274, 23577-23583. [CrossRef] [PubMed]

18. Simopoulos, A. An increase in the Omega-6/Omega-3 fatty acid ratio increases the risk for obesity. Nutrients 2016, 8, 128. [CrossRef] [PubMed]

19. Mckenney, J.M.; Sica James Mckenney, D.M. Omega-3 fatty acids prescription omega-3 fatty acids for the treatment of hypertriglyceridemia. Am. J. Health Syst. Pharm. 2007, 64, 595-605. [CrossRef] [PubMed]

20. Harris, W.S. $n$-3 fatty acids and serum lipoproteins: Human studies. Am. J. Clin. Nutr. 1997, 65, S1645-S1654. [CrossRef]

21. De Araújo, T.V.; Andrade, E.F.; Lobato, R.V.; Orlando, D.R.; Gomes, N.F.; de Sousa, R.V.; Zangeronimo, M.G.; Pereira, L.J. Effects of beta-glucans ingestion (Saccharomyces cerevisiae) on metabolism of rats receiving high-fat diet. J. Anim. Physiol. Anim. Nutr. (Berl.) 2016. [CrossRef] [PubMed]

22. Reeves, P.G. Components of the AIN-93 diets as improvements in the AIN-76A diet. J. Nutr. 1997, 127, S838-S841.

23. Association of Official Analytical Chemists (AOAC). Association of Official Analytical Chemists Official Methods of Analysis of AOAC International, 17th ed; AOAC International: Gaithersburg, MD, USA, 2000. Available online: http:/ / www.aoac.org/aoac_prod_imis/AOAC/Publications/Official_Methods_of_Analysis/ AOAC_Member/Pubs/OMA/AOAC_Official_Methods_of_Analysis.aspx (accessed on 6 November 2017).

24. Lee, M. Determination of the surface area of the white rat with its application to the expression of metabolic results. Am. J. Physiol. Leg. Content 1929, 89, 24-33. [CrossRef]

25. Bernardis, L.L.; Patterson, B.D. Correlation between "Lee index" and carcass fat content in weanling and adult female rats with hypothalamic lesions. J. Endocrinol. 1968, 40, 527-528. [CrossRef] [PubMed]

26. Folch, J.; Lees, M.; Sloane Stanley, G.H. A simple method for the isolation and purification of total lipides from animal tissues. J. Biol. Chem. 1957, 226, 497-509. [PubMed] 
27. Martinez-Flores, H.; Chang, Y.K.; Martinez-Bustos, F.; Sgarbieri, V. Effect of high fiber products on blood lipids and lipoproteins in hamsters. Nutr. Res. 2004, 24, 85-93. [CrossRef]

28. Yang, R.-L.; Shi, Y.-H.; Hao, G.; Li, W.; Le, G.-W. Increasing oxidative stress with progressive hyperlipidemia in human: Relation between malondialdehyde and atherogenic index. J. Clin. Biochem. Nutr. 2008, 43, 154-158. [CrossRef] [PubMed]

29. Page, K.A.; Hartzell, D.L.; Li, C.; Westby, A.L.; Della-Fera, M.A.; Azain, M.J.; Pringle, T.D.; Baile, C.A. Beta-Adrenergic receptor agonists increase apoptosis of adipose tissue in mice. Domest. Anim. Endocrinol. 2004, 26, 23-31. [CrossRef] [PubMed]

30. Velasco, M.V.R.; Tano, C.T.N.; Machado-Santelli, G.M.; Consiglieri, V.O.; Kaneko, T.M.; Baby, A.R. Effects of caffeine and siloxanetriol alginate caffeine, as anticellulite agents, on fatty tissue: Histological evaluation. J. Cosmet. Dermatol. 2008, 7, 23-29. [CrossRef] [PubMed]

31. Magliano, D.C.; Bargut, T.C.L.; de Carvalho, S.N.; Aguila, M.B.; Mandarim-de-Lacerda, C.A.; Souza-Mello, V. Peroxisome proliferator-activated receptors-alpha and gamma are targets to treat offspring from maternal diet-induced obesity in mice. PLoS ONE 2013, 8, e64258. [CrossRef] [PubMed]

32. Vickers, S.P.; Cheetham, S.C.; Headland, K.R.; Dickinson, K.; Grempler, R.; Mayoux, E.; Mark, M.; Klein, T. Combination of the sodium-glucose cotransporter-2 inhibitor empagliflozin with orlistat or sibutramine further improves the body-weight reduction and glucose homeostasis of obese rats fed a cafeteria diet. Diabetes Metab. Syndr. Obes. 2014, 7, 265-275. [CrossRef] [PubMed]

33. Ferreira, D.F. Sisvar: A computer statistical analysis system. Ciência e Agrotecnologia 2011, 35, 1039-1042. [CrossRef]

34. Estadella, D.; Oyama, L.M.; Bueno, A.A.; Habitante, C.A.; Souza, G.I.; Ribeiro, E.B.; Motoyama, C.S.M.; Oller do Nascimento, C.M. A palatable hyperlipidic diet causes obesity and affects brain glucose metabolism in rats. Lipids Health Dis. 2011, 10, 168. [CrossRef] [PubMed]

35. Nascimento, A.F.; Sugizaki, M.M.; Leopoldo, A.S.; Lima-Leopoldo, A.P.; Luvizotto, R.A.M.; Nogueira, C.R.; Cicogna, A.C. A hypercaloric pellet-diet cycle induces obesity and co-morbidities in Wistar rats. Arq. Bras. Endocrinol. Metabol. 2008, 52, 968-974. [CrossRef] [PubMed]

36. Sampey, B.P.; Vanhoose, A.M.; Winfield, H.M.; Freemerman, A.J.; Muehlbauer, M.J.; Fueger, P.T.; Newgard, C.B.; Makowski, L. Cafeteria diet is a robust model of human metabolic syndrome with liver and adipose inflammation: Comparison to high-fat diet. Obesity (Silver Spring) 2011, 19, 1109-1117. [CrossRef] [PubMed]

37. Rosini, T.C.; Da Silva, A.S.R.; De Moraes, C. Diet-induced obesity: Rodent model for the study of obesity-related disorders. Revista da Associação Médica Brasileira (Engl. Ed.) 2012, 58, 383-387.

38. Priego, T.; Sánchez, J.; García, A.P.; Palou, A.; Picó, C. Maternal dietary fat affects milk fatty acid profile and impacts on weight gain and thermogenic capacity of suckling rats. Lipids 2013, 48, 481-495. [CrossRef] [PubMed]

39. Pate, R.R.; Taverno Ross, S.E.; Liese, A.D.; Dowda, M. Associations among physical activity, diet quality and weight status in US adults. Med. Sci. Sports Exerc. 2015, 47, 743-750. [CrossRef] [PubMed]

40. Nakatani, T.; Kim, H.-J.; Kaburagi, Y.; Yasuda, K.; Ezaki, O. A low fish oil inhibits SREBP-1 proteolytic cascade, while a high-fish-oil feeding decreases SREBP-1 mRNA in mice liver: Relationship to anti-obesity. J. Lipid Res. 2003, 44, 369-379. [CrossRef] [PubMed]

41. Ren, B.; Thelen, A.P.; Peters, J.M.; Gonzalez, F.J.; Jump, D.B. Polyunsaturated fatty acid suppression of hepatic fatty acid synthase and S14 gene expression does not require peroxisome proliferator-activated receptor alpha. J. Biol. Chem. 1997, 272, 26827-26832. [CrossRef] [PubMed]

42. Gao, Q.; Jia, Y.; Yang, G.; Zhang, X.; Boddu, P.C.; Petersen, B.; Narsingam, S.; Zhu, Y.-J.; Thimmapaya, B.; Kanwar, Y.S.; et al. PPAR $\alpha$-Deficient ob/ob obese mice become more obese and manifest severe hepatic steatosis due to decreased fatty acid oxidation. Am. J. Pathol. 2015, 185, 1396-1408. [CrossRef] [PubMed]

43. Deng, X.; Dong, Q.; Bridges, D.; Raghow, R.; Park, E.A.; Elam, M.B. Docosahexaenoic acid inhibits proteolytic processing of sterol regulatory element-binding protein-1c (SREBP-1c) via activation of AMP-activated kinase. Biochim. Biophys. Acta 2015, 1851, 1521-1529. [CrossRef] [PubMed]

44. Horton, J.D.; Shimomura, I.; Brown, M.S.; Hammer, R.E.; Goldstein, J.L.; Shimano, H. Activation of cholesterol synthesis in preference to fatty acid synthesis in liver and adipose tissue of transgenic mice overproducing sterol regulatory element-binding protein-2. J. Clin. Investig. 1998, 101, 2331-2339. [CrossRef] [PubMed] 
45. Sposito, A.C.; Caramelli, B.; Fonseca, F.A.H.; Bertolami, M.C.; Afiune Neto, A.; Souza, A.D.; Lottenberg, A.M.P.; Chacra, A.P.; Faludi, A.A.; Loures-Vale, A.A.; et al. IV Brazilian guideline for dyslipidemia and atherosclerosis prevention: Department of atherosclerosis of Brazilian society of cardiology. Arq. Bras. Cardiol. 2007, 88 (Suppl. 1), 2-19. [CrossRef] [PubMed]

46. Weitz, D.; Weintraub, H.; Fisher, E.; Schwartzbard, A.Z. Fish oil for the treatment of cardiovascular disease. Cardiol. Rev. 2010, 18, 258-263. [CrossRef] [PubMed]

47. Sabarense, C.M.; Mancini Filho, J. Effect of the partially hydrogenated vegetable fat on the incorporation of trans fatty acids in rat tissues. Rev. Nutr. 2003, 16, 399-407. [CrossRef]

48. Silva, A.P.; Nascimento, L.; Osso, F.; Mizurini, D.; Campos, D.; De Martinez, A.M.B.; Do Carmo, M.D.G.T. Plasma fatty acids, lipid metabolism and lipoproteins in rats fed on palm oil and partially hydrogenated soybean oil. Rev. Nutr. 2005, 18, 229-237. [CrossRef]

49. Stawarska, A.; Białek, A.; Tokarz, A. Heating of vegetable oils influences the activity of enzymes participating in arachidonic acid formation in Wistar rats. Nutr. Res. 2015, 35, 930-938. [CrossRef] [PubMed]

50. Jurgoński, A.; Juśkiewicz, J.; Zduńczyk, Z. A high-fat diet differentially affects the gut metabolism and blood lipids of rats depending on the type of dietary fat and carbohydrate. Nutrients 2014, 6, 616-626. [CrossRef] [PubMed]

51. Hirosumi, J.; Tuncman, G.; Chang, L.; Görgün, C.Z.; Uysal, K.T.; Maeda, K.; Karin, M.; Hotamisligil, G.S. A central role for JNK in obesity and insulin resistance. Nature 2002, 420, 333-336. [CrossRef] [PubMed]

52. Sabio, G.; Das, M.; Mora, A.; Zhang, Z.; Jun, J.Y.; Ko, H.J.; Barrett, T.; Kim, J.K.; Davis, R.J. A stress signaling pathway in adipose tissue regulates hepatic insulin resistance. Science 2008, 322, 1539-1543. [CrossRef] [PubMed]

53. Kahn, S.; Hull, R.; Utzschneider, K. Mechanisms linking obesity to insulin resistance and type 2 diabetes. Nature 2006, 444, 840-846. [CrossRef] [PubMed]

54. Fonseca-Alaniz, M.H.; Takada, J.; Alonso-Vale, M.I.C.; Lima, F.B. The adipose tissue as a regulatory center of the metabolism. Arq. Bras. Endocrinol. Metabol. 2006, 50, 216-229. [CrossRef] [PubMed]

55. Matsubara, M.; Katayose, S.; Maruoka, S. Decreased plasma adiponectin concentrations in nondiabetic women with elevated homeostasis model assessment ratios. Eur. J. Endocrinol. 2003, 148, 343-350. [CrossRef] [PubMed]

56. Zamin, J.I.; de Mattos, A.A.; Perin, C.; Ramos, G.Z. The importance of AST/ALT rate in nonalcoholic steatohepatitis diagnosis. Arq. Gastroenterol. 2002, 39, 22-26. [PubMed]

57. Volp, A.C.P.; Alfenas, R.; Costa, N.M.B.; Minim, V.P.R.; Stringueta, P.C.; Bressan, J. Inflammation biomarkers capacity in predicting the metabolic syndrome. Arq. Bras. Endocrinol. Metabol. 2008, 52, 537-549. [CrossRef] [PubMed]

58. Henderson, R.J.; Tocher, D.R. The lipid composition and biochemistry of freshwater fish. Prog. Lipid Res. 1987, 26, 281-347. [CrossRef]

59. Serhan, C.N.; Petasis, N.A. Resolvins and protectins in inflammation resolution. Chem. Rev. 2011, 111, 5922-5943. [CrossRef] [PubMed]

60. Weylandt, K.H.; Chiu, C.-Y.; Gomolka, B.; Waechter, S.F.; Wiedenmann, B. Omega-3 fatty acids and their lipid mediators: Towards an understanding of resolvin and protectin formation. Prostaglandins Lipid Mediat. 2012, 97, 73-82. [CrossRef] [PubMed]

61. Tjonahen, E.; Oh, S.F.; Siegelman, J.; Elangovan, S.; Percarpio, K.B.; Hong, S.; Arita, M.; Serhan, C.N. Resolvin E2: Identification and anti-inflammatory actions: Pivotal role of human 5-lipoxygenase in resolvin E series biosynthesis. Chem. Biol. 2006, 13, 1193-1202. [CrossRef] [PubMed]

62. Sun, C.; Wei, Z.; Li, Y. DHA regulates lipogenesis and lipolysis genes in mice adipose and liver. Mol. Biol. Rep. 2011, 38, 731-737. [CrossRef] [PubMed]

(C) 2018 by the authors. Licensee MDPI, Basel, Switzerland. This article is an open access article distributed under the terms and conditions of the Creative Commons Attribution (CC BY) license (http://creativecommons.org/licenses/by/4.0/). 